め, 両液の熱交換率のよいことが重要な問題となつて くる。

脱䟽率を $90 \%$ 以上に保持するための條件として，当 社においては (i) 吸収塔大口吸収液温度 $30 \sim 35^{\circ} \mathrm{C}$, 吸収液量 $50 \mathrm{t} / \mathrm{hr}$ (ii ) 再生塔出口再生液中の残留全硫 黄分 $1.27 \sim 2.14 \mathrm{~g} / /$ (iii) 再生塔真空度 $90 \mathrm{mmHg}$ が必 要である。

当社ではヴァキウム・カーボネート法脱硫塔の後に シーボルト法脱酼塔を使用しているが，これによる脱 硫率も $90 \%$ 程度で一応满足すべき状態である。

$$
\text { IV 結 言 }
$$

以上でヴァキウム・カーボネート法の簡単な紹介を 兼ね, 当工場における操業について述へたが，わが国 初めての装置であり，運転に当つては種々の困難が予 想されたにもかかわらず，運転開始以来此較的順調な 運転を継続している。しかしながら始運転以来日も浅 く，脱硫率に正潘す諸要因についてはさらに系統的な 研究が必要であると考えている。この装置の利点とし て（1）装置が簡単で運転管理も比較的容易である こと（2）メーダ灰の消費が少く，加熱用熱源もほ とんど不要で，経費が非常に安価であること（3）
硫化水素ガスとして純度の高いものが得られること (4) 硫化水素ガスとともにシアン化水素ガスも回収 できること

などであつて優れた脱硫法であることがいえよう。

目下当社では硫化水素については硫黄またはチォ尿 素なぞへの利用を考光実際に製品化しているものも亦 り,ささらにシアン化水素の回収も興味ある問題と考光 ている。

文献

1) H. A. Gollmar, Ohap. 26 of "Ohemistry of Coal Utilization" edited by H. H. Lowry

2 ) R. M. Reed \& C. Updegraft, Ind. Eng. Ohem., 42, 2269 (1950).

$3)$ F. W. Sperr \& R. E. Hall, U. S. patent, 1,533,773 (1925).

4 ) A. R. Rowell, ibid, 2,242,323 (1941).

5 ) H. A.Gollmar, ibid, 2,379,076 (1945).

$6)$ M. L. Kasterns \& R. Barraclough, Ind. Eng. Ohem., 43, 1882 (1951).

7) シュマーレンバッ八, コールタール, 5, 21(1953).

\title{
The Vacuum Carbonate Desulphurization
}

by Toshio Taguchi \& Susumu Yoshida

(Miike Gōsei Kōgyō Co.)

SYNOPSIS :-The so-called vacuum carbonate method for desulphurizing $\mathrm{H}_{2} \mathrm{~S}$ contained in carbonizing gas was invented by the American Koppers Co. in 1945. The first installation of the method in this country commenced operation last summer in a Miike factory in Kyūshū and showed good results. The principle, procedures and restilts were reviewed.

U.D.C. 662.62 .094 .34

\section{石炭の気相空気酸化に関する研究 (I)}

流動層反応による反応速度, 酸化

生成物および区応機構について

一昭和 28 年 11 月石炭科学講演——

東京大学工学部 神谷佳 男

要旨 流動厤反応裝置を傎用して石炭の空気酸化（主に $200 \sim 300^{\circ} \mathrm{C}$ ）に関する 2,3 の問題を考 
察した。

酸化による石炭の性質の変化を知るために粘結性（ボタン法）揮発分，重量变化，フミン酸测定

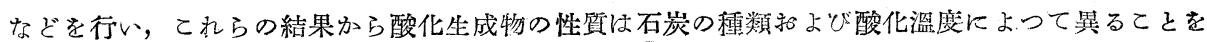

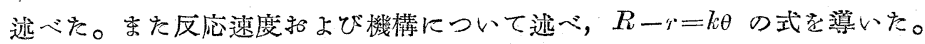

\section{I 緒言}

石炭の気相空気酸化の研究は，風化抢よび自然発火 現象の調查と構造研究に端を発しているが，現今では 積極的に石炭の品質の变化を利用する立場から研究が 行われている。

空気酸化法の主な目的は，石炭のコークス化時の性 質を改良することと，有機酸の製造にあるといえる。 空気酸化により石炭はえの粘結性，可塑性を竑しく減 少するから，粉炭を流動層なぞで連続的にがス化，乾 溜する時にはこの性質が利用されるし，生成するター一 ル，ガスコークスの性質および量にも大きな変化を 与えることができる。

また酸化された石炭は試薬に対して著しく分解が容 易になることが硝酸处理およびアルカリ，処理の場合に ついて報告されており，相当量の酸素が結合すること と相俟つて有機酸の直接製造抢よび引続いての液相睃 化の前処理法として有利であることが認められてい る。

従来の研究結果をみると, $100^{\circ} \mathrm{C}$ 附近の温度では Winmill 1), Schmidt 4)，その他1)の反応速度などに ついての研究があり，100〜200 ${ }^{\circ}$ Cでは Reilly ${ }^{2)}$, Wh-

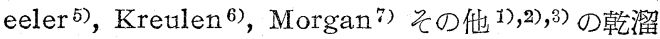
時の性質,フミン酸の生成などについての研究がある。 $200^{\circ} \mathrm{C}$ 以上では Kreulen ${ }^{6), 8)}$ Lefebure ${ }^{9)}$, Fuchs ${ }^{10)}$, その他 $\left.\left.{ }^{32}, 5\right), 11\right)$ がフミン酸, 粘結性, 反応酸素の分布 状態について報告している。最近のものとしては Grosskinsky ${ }^{12)}$, Huck ${ }^{13)}$ ，Roetheli ${ }^{14)}$ ，岩崎氏 ${ }^{16)}$ ，樋

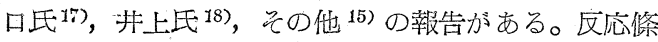
件の生成物におよぼす影響抢よび区応速度については さらに詳細な研究が必要であると思われる。

笔者は固体一気体の反応系では最も有利な流動層反 応により，主に $200 〜 300^{\circ} \mathrm{C}$ の範国で実験を行つた。 その結果反応特性，反応速度なとについて知り得たこ とについて報告する。

\section{II 実 駧 裝 置}

固体一気体系反応では，内部の温度が均一に保たれ しかも反応速度の大きい流動層反応装置を使用するこ とが，学閵的並びに工業的立場から非常に有利なこと であろう。

従来の酸化方法では外熱の場合はもちろん気体によ
る内熱の場合でも，かなりの不均一温度分布は邀けら れず，部分的過熱が起きたりするし，また反応速度も 熱打よび気体の流れの不均一のために空間位置で異な るために生成物が不均一になる欠点を持つている。

第1図 流動筒酸化裝置

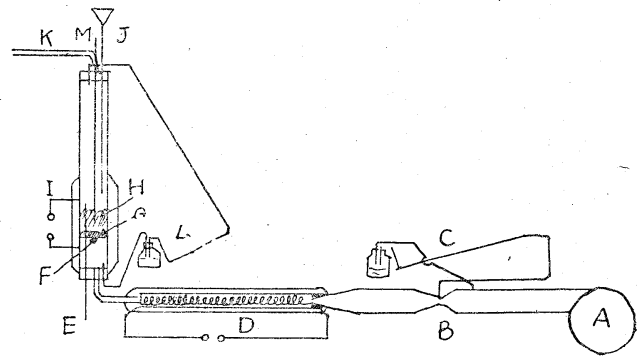
$\mathrm{A}:$ 䢪 風器
$\mathrm{B}:$ r゙ュンチュリ計
$\mathrm{C}:$ ガス流速测定用傾斜マノメータ
D : 空気予熱器
$\mathrm{E}:$ 酸化炭排出管
$\mathrm{F}:$ 金綪
$\mathrm{G}:$ 鉄 粉
$\mathrm{H}$ : 石㞸流動尿
I : 加 熱 線
$\mathrm{J}:$ 石炭投入管
$\mathrm{K}:$ 吕出口
$\mathrm{L}$ : 流勤層差王計
$\mathrm{M}$ : 熱 電 対

本実験の装置は第 1 図に示した。反応塔は内径 60 $\mathrm{mm}$ の硬質がラス管を便用し，視き空から内部の流動 状態が観察されるようにした。送風器から送られた空 気は室温で傾斜マノメータ存附けたヴュンチュリ評に より測定した。次いで内熱型予熱器により約 $180^{\circ} \mathrm{C} ま$ で温度を上景させ，反応塔の下部から送入して約 $1 \mathrm{~cm}$ の厚さの 20〜30mesh の鉄粉層により整流して石炭古 流動させた後に排出した。

空気流速は反応温度の空気中における石炭粒子の終 端速度の 0.3 倍の程度とし，反応層が完全流動状態に あるようにした。酸化すべき粉宸は上部から挆大した が，投大後 5 10min 以内に所期反応温度に達するよ うに運転した。分析用試料は所期温度に達した時に採 取されたもの存区温時間 $0 \mathrm{~min}$ の試料とし，その後各 時間毎に排出管を下げて試料を採取した。採取時間の 誤差は $1 \mathrm{~min}$ 以内であつた。

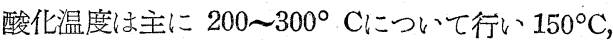
$170^{\circ} \mathrm{C}, 180^{\circ} \mathrm{C}, 340^{\circ} \mathrm{C}, 420^{\circ} \mathrm{C}$ についも 1 例うつ行 
つた。温度の誤善は $260^{\circ} \mathrm{C}$ 以下では $2^{\circ} \mathrm{C}$ 以内であるが， $300^{\circ} \mathrm{C}$ 以上では反応初期は温度調節が難しいために 5

〜 $10^{\circ} \mathrm{C} に$ よぶこともあつた。

岸種は三池，大夕張宸を主とし，田川，磨町，米国 炭についても少数実験した。試料は $60 \mathrm{mesh}$ 以下 $50 \%$ 程度に粉砕したもの范節分し，40１20meshの範国を 酸化した。反応時間は0〜120 minまで取つた。

\section{III 分析手段および方法}

酸化による石炭の性質の変化, おょびその測定法に ついては非常に多くの記載がある。1),22,37,(11)笔者は定 量的な值を与え，かつ用途にも直結した分析方法とし て適当と思われる揮発分, 重量变化, 粘結性, アルカ リ処理を採つた。

（1）粘結性 風化によつて粕結性が著しく減少す ることは周知の事実である。測定方法も種々あるが， コークス形成時に固体から流体になり固化する物質の 量に敏感であると考えられ，操作も簡単で再現性のよ いボタン法を適用した。

（2）揮発分 酸化に上る粘結性の低下否岩構造 が強固になるためと考光るならば，熱分解により気化 する物質の量を示す揮発分も変化すると考えられる。 ボタン法は粘結物の量觉示すと考えられるが, 揮発分 はコークスのみかけの密度を決定するからともにコー クスの强度に大きな影響を持つ。

(3) 重量変化比 反応は石炭と酸素との間の結合 抢よび分解反応にあるから， $\mathrm{CO}_{2}, \mathrm{H}_{2} \mathrm{O}, \mathrm{CO}$ 年の他 としての石炭中の岸菜, 水素, 酸素の気化による石炭 の重量減少および酸慈附加による重量增加の差が重量 の変化となつて現われてくる。

測定方法は最初灰分比から行つたが精密な值が得ら れないので，流動層の上下美圧を勾配が／５の傾斜、， メータで測定し比較した。流動層内の滞留粒子重量を $W$, 反応層横断面積党 $A$ とすると羑压 $\Delta P$ はほとんど $W / A$ に等しいががス流速, 滞留粒子の径, 量などが 一定の場合には $\Delta P$ が $W に$ 比例することは正確であ る。

（4）アルカリ处理 酸化崖を500mg とり $200 \mathrm{cc} の$ $2 \%-\mathrm{NaOH}$ 溶液で $60 \mathrm{~min}$ 靠沸し, 濾液を塩酸で中和 して沈澱しだ、ミン酸の重量它測定した。予備実験に おいて酸化炭の重量減少の測定芭行つてみたが，アル カリ处理後の酸化炭は酸化され易く重量が変化し易い 上に，実験誤美が測定すべき值に対して相対的に大き いので,この方法はとらなかつた。

フミン酸の量は加水分解し易い酸素結合基の生成量 によつて変化すると思われる。

\section{IV 実 験 結 果}

第 \表 空気酸化によるボタン指数および 揮登分の変化

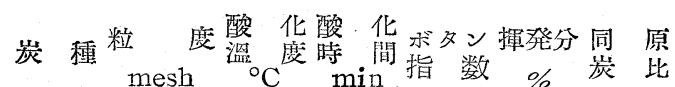
三 池 $60 \sim 80 \quad 180 \quad 60 \quad 8.5$

$\begin{array}{lllll}200 & 0 & 9 & 42.2 & 1.00\end{array}$

\begin{tabular}{|c|c|c|c|c|c|}
\hline \multirow{5}{*}{\multicolumn{2}{|c|}{200}} & 10 & 9 & 40.9 & 0.969 \\
\hline & & 30 & 7.5 & 38.7 & 0.917 \\
\hline & & 60 & 3 & 38.4 & 0.909 \\
\hline & & 90 & 1.5 & 37.6 & 0.892 \\
\hline & & 120 & 1 & - & - \\
\hline \multirow{6}{*}{\multicolumn{2}{|c|}{220}} & 0 & 9 & - & - \\
\hline & & 10 & 7 & - & - \\
\hline & & 20 & 4 & - & - \\
\hline & & 30 & 3 & - & - \\
\hline & & 45 & 1 & - & - \\
\hline & & 60 & 1 & - & - \\
\hline \multirow{6}{*}{\multicolumn{2}{|c|}{240}} & 0 & 8.5 & 40.0 & 0.948 \\
\hline & & 10 & 3 & 38.6 & 0.918 \\
\hline & & 20 & 1.5 & - & - \\
\hline & & 30 & 1 & 36.4 & 0.863 \\
\hline & & 60 & 1 & 36.6 & 0.866 \\
\hline & & 90 & 1 & 35.7 & 0.846 \\
\hline \multirow{4}{*}{\multicolumn{2}{|c|}{250}} & 0 & 9 & - & - \\
\hline & & 5 & 4 & - & - \\
\hline & & 10 & 2.5 & 38.8 & 0.920 \\
\hline & & 15 & 1.5 & 39.0 & 0.924 \\
\hline \multirow{3}{*}{\multicolumn{2}{|c|}{. }} & 20 & 1 & 36.0 & 0.853 \\
\hline & & 30 & 1 & 36.4 & 0.863 \\
\hline & & 60 & 1 & 35.1 & 0.832 \\
\hline \multirow{6}{*}{\multicolumn{2}{|c|}{260}} & 0 & 7.5 & 40.4 & 0.957 \\
\hline & & 10 & 2.5 & 38.0 & 0.900 \\
\hline & & 20 & 2 & - & - \\
\hline & & 30 & 2 & 35.8 & 0.848 \\
\hline & & 60 & 2 & 35.3 & 0.037 \\
\hline & & 0 & 4.5 & 38.4 & 0.910 \\
\hline & & 5 & 3 & - & - \\
\hline & & 10 & 3 & 36.4 & 0.863 \\
\hline & & 20 & 3 & - & - \\
\hline & & 30 & 3 & 35.0 & 0.830 \\
\hline & & 60 & 3 & 34.6 & 0.820 \\
\hline & & 90 & 3 & - & - \\
\hline \multirow{2}{*}{$50 \sim 60$} & 200 & 0 & 9 & 42.5 & 1.00 \\
\hline & & 10 & 9 & 41.7 & 0.983 \\
\hline
\end{tabular}


炭種粒 喥酸化酸华ボタン揮発分同原 三 池 50 60 $200 \quad 30 \quad 7.5 \quad 40.4 \quad 0.953$

$\begin{array}{llll}60 & 3.5 & 39.0 & 0.920\end{array}$

$\begin{array}{llll}90 & 2 & 38.7 & 0.913\end{array}$

240

$\begin{array}{rlll}0 & 8 & - & - \\ 10 & 4.5 & - & - \\ 20 & 3.5 & - & - \\ 30 & 3 & - & - \\ 40 & 2.5 & - & - \\ 50 & 2.5 & - & - \\ 60 & 2.5 & - & -\end{array}$

250

$\begin{array}{llll}0 & 8 & 42.4 & 1.00\end{array}$

$\begin{array}{llll}10 & 3 & 38.3 & 0.903\end{array}$

$\begin{array}{llll}30 & 2.5 & 37.1 & 0.875\end{array}$

$\begin{array}{llll}45 & 2.5 & 36.5 & 0.860\end{array}$

$\begin{array}{llll}60 & 2.5 & 35.2 & 0.830\end{array}$

$\begin{array}{lllll}300 & 10 & 3 & 37.9 & 0.882\end{array}$

$\begin{array}{llll}30 & 3 & - & -\end{array}$

$90 \cdot 3 \quad-\quad-$

$\begin{array}{llllll}100 \sim 120 & 200 & 0 & 9 & 41.2 & 0.981\end{array}$

$\begin{array}{llll}10 & 9 & 39.3 & 0.935\end{array}$

$\begin{array}{llll}30 & 7 & 37.3 & 0.888\end{array}$

$\begin{array}{llll}60 & 1.5 & 36.0 & 0.857\end{array}$

$\begin{array}{llll}90 & 1 & 36.5 & 0.868\end{array}$

$\begin{array}{lllll}240 & 0 & 9 & 42.0 & 1.00\end{array}$

$\begin{array}{llll}5 & 3 & 39.0 & 0.928\end{array}$

$\begin{array}{lllll}10 & 2 & 37.8 & 0.900\end{array}$

$\begin{array}{llll}15 & 1.3 & 36.5 & 0.870\end{array}$

$20 \quad 1 \quad$ - $\quad$ -

$\begin{array}{llll}30 & 1 & 36.3 & 0.864\end{array}$

$\begin{array}{llll}60 & 1 & 34.8 & 0.828\end{array}$

$\begin{array}{llllll}\text { 大夕張 } 60 \sim 100 & 150 & 0 & 8.5 & 42.0 & 1.00\end{array}$

$30 \quad 8.5 \quad-\quad$ -

$\begin{array}{llll}60 & 8.5 & 41.5 & 0.99\end{array}$

$\begin{array}{lllll}170 & 0 & 9 & 41.9 & 1.00\end{array}$

$\begin{array}{llll}30 & 9 & 41.4 \quad-\end{array}$

$\begin{array}{llll}60 & 8.5 & 41.1 & -\end{array}$

$\begin{array}{lllll}200 & 0 & 8.5 & 42.0 & 1.00\end{array}$

$\begin{array}{llll}10 & - & 41.5 \quad 0.987\end{array}$

$\begin{array}{llll}30 & 7.5 & 39.3 & 0.937\end{array}$

$\begin{array}{llll}60 & 3 & 38.8 & 0.928\end{array}$

$\begin{array}{lllll}220 & 0 & 8.5 & 41.6 & 0.99\end{array}$

$\begin{array}{llll}10 & 7.5 \quad- & -\end{array}$

$\begin{array}{llll}20 & 3 & 39.2 & 0.936\end{array}$

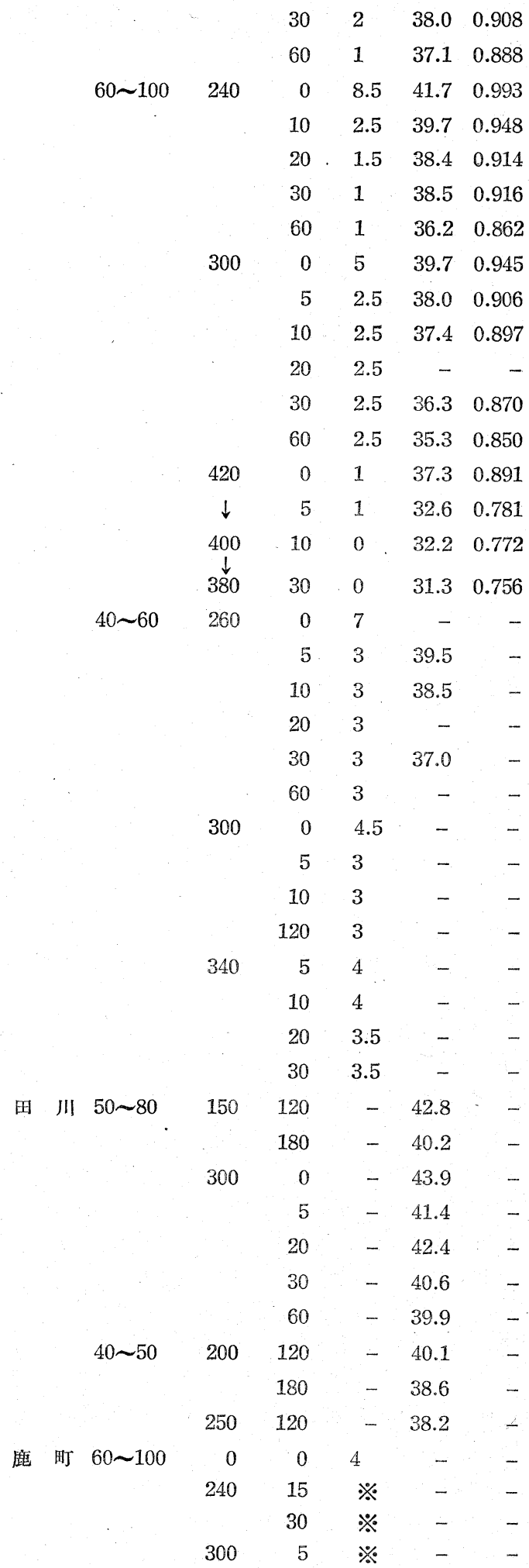


炭種粒度酸化酸华ボタン揮発分同原
mesh ${ }^{\circ} \mathrm{C}$ min 指数 $\%$ 炭比

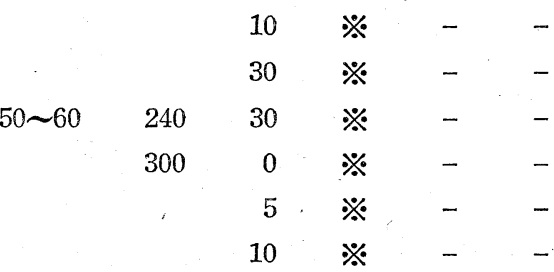

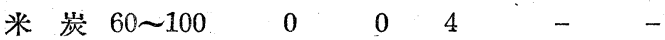

$\begin{array}{rrrrr}240 & 30 & \circledast & - & - \\ 300 & 5 & ※ & - & - \\ & 10 & ※ & - & -\end{array}$

[碃溇]

1. 原炭の無水炭についての揮発分, 灰分は次の よらである。

炭種粒度揮発分灰 $\%$

三 池 $50 \sim 60 \quad 42.5 \quad 14$

$60 \sim 80 \quad 42.2 \quad 15$

$100 \sim 120 \quad 24.0 \quad 17$

大夕張 $40 \sim 60 \quad 42.0 \quad 4.3$

$60 \sim 100 \quad 42.0 \quad 4.4$

田 川 $40 \sim 50 \quad 44.0 \quad 13.5$

$50 \sim 80 \quad 44.0 \quad 14.7$

2. 鹿町, 米炭の※汶全然成型しないので汸な く，少しふくらんだボタン指数で 2 の程鹿，く ずれ易いボタン型である。表面が乎円型であり 規格の図に合々ない上にくずれ易いために※と した。すべて同型である。

3. 揮発分の值々舤水炭を基集にして取つた。三 池炭, 大夕張炭の酸化炭の水分は全部 $1 \%$ 以下 であり，大部分は $0.5 \%$ 以下である。

(a) ボタン指数

第 1表，第 2,3,4 図に示す。第 2,3 図は粒径を一定 とした時の酸化温度と時間の变化に対してのボタン指 数の変化を示した。第 4 四には同一温度で粒径を変化 させた時の反応速度を比較した。

3つの区からは，粘結性の值が 或時間酸化後は一定

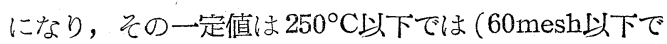
は）一定であるが， $260^{\circ} \mathrm{C}$ 以上では異つていることが 知られる。図には示されていないが，鹿町，来孷では

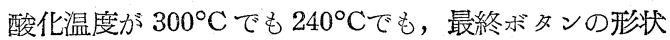
は同椂であつた。

このような事情は，三池と大夕張炭は性質が似てい るが，鹿町，米炭などの高炭化度のものとは，構造に
第 2 図 ボタン指数の変化（三池）

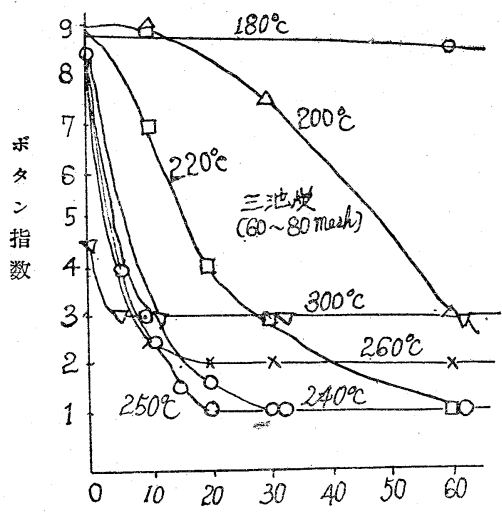

酸化時間 (min)

第3 図 ボタン指数の変化 (大夕張)

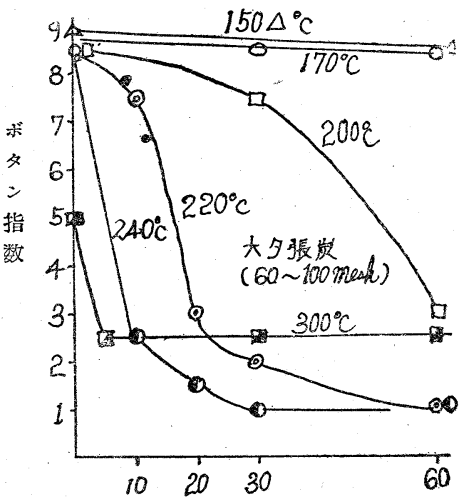

酸化封間 (min)

第4図 ボタン指数变化曲線（粒径の影響）

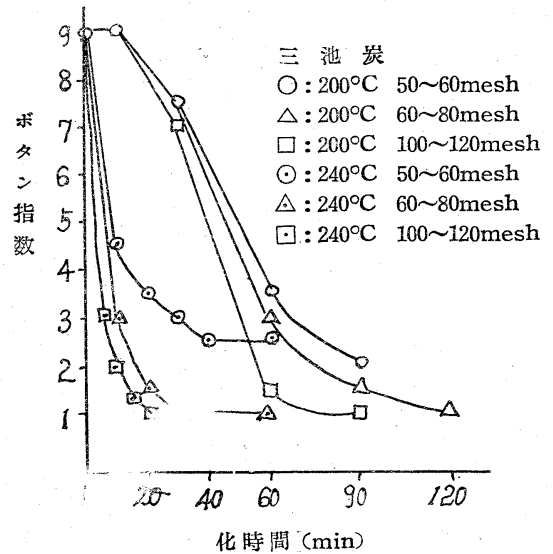


由来する反応性がかなり異つたものであること，およ び同一㞸種でも 50〜60mesh と 60〜80mesh の間の反 応性の差異にみるように，穊分時に成分の異つたもの に別かれることを示している。

\section{第 5 図 電気炉中でのボタン}

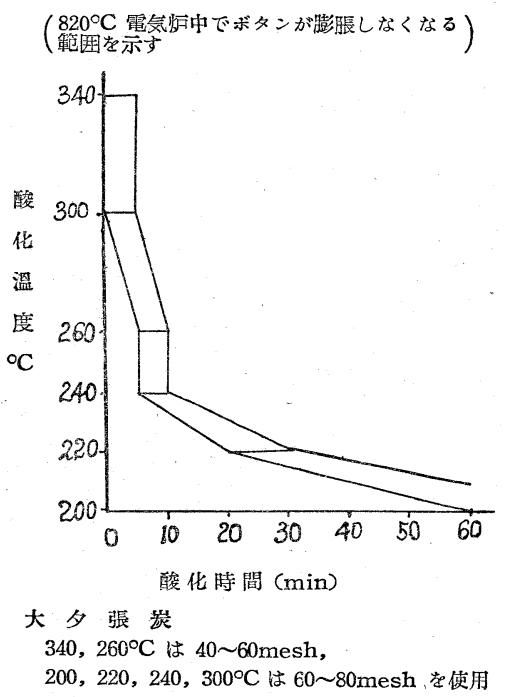

なお，ボタン法はボタンが非常に膨らみ易い條件で 实験を行つているので, 実際のコークス化時の性質と 比較するために， $820^{\circ} \mathrm{C}$ の電気炬中でボタンを作り， 得られたコークスが膨脤せず，しかも砂磍面を示さな いような酸化時間の範囲を各温度につき図示したのが 第 5 図である。揮発分測定の場合にみられるコークス ボタンについての同様な観察はほとんど上記の方法の 結果と一致するが，精度に捣てて劣つている。

この結果は第1表と比較すれば容易に解るように, ほほボタン指数が 3 の程度の酸化度に一致する。

\section{第 6 図 揮発分変化曲線（三池）}

三池宸 (60 80mesh)

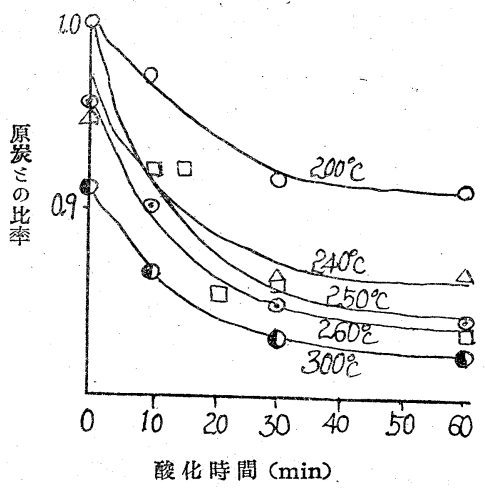

第7図 揂発分（大夕張）

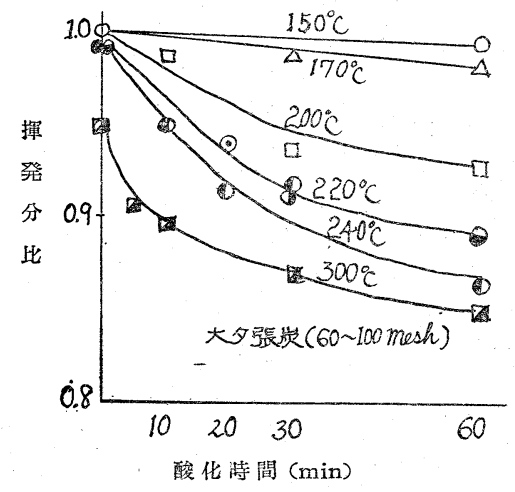

第 8 図 揮発分变化苚線（粒径の影響） 三池炭使用

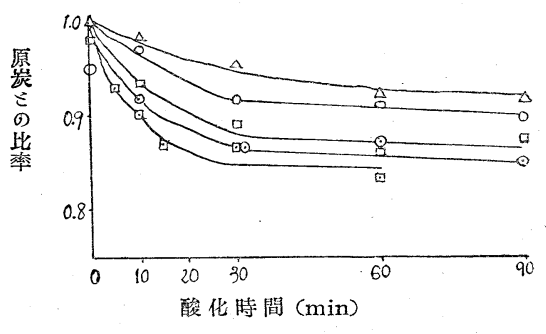

三池宸 $\triangle: 200^{\circ} \mathrm{C} \quad 50 \sim 60 \mathrm{mesh}$
$0:$ : 60 80 mesh
$\square:$ I) 100 120mesh
$\odot: 240^{\circ} \mathrm{C} \quad 60 \sim 80 \mathrm{mesh}$
$\square:$ I) 100 120mesh

(b) 揮発分

第 6,7,8図に示したように，ボタン指数の場合とは 異り，高温程，長時間程，揮発分は減少する。第 8 図 では粒径の影響が現われているのがみられる。粒径の 小さい程単位重量当りの表面積が大きいことが反応速 度に效いている。次に述べるように重量はほとんど変 化していないから，不揮発分は逆に堌加していて，揮 発分变化曲線を逆にしたような変化曲線を示す。

(c) 重量変化

反応條件总一定に保ち反応層内の石孷を外部に出さ ないで圧降下の変動を読んだが，60〜80mesh の試料 では $200^{\circ} \mathrm{C}, 240^{\circ} \mathrm{C}, 300^{\circ} \mathrm{C}$ の各温度の酸化で $2 \mathrm{hr}$ 以 内の時間では，変動は $1 \%$ 以内であり，低温では上昇 の傾问が みられるが誤差範困である。従つて200〜300 ${ }^{\circ} \mathrm{C}$ では $2 \mathrm{hr}$ 以内の反応ではほとんど重量は変化しな いといつて差卖えない。（所定の温度になるまでに水 分は蒸発しているとみられるから，無水を基淮にした 重量変化についてである) 
第 2表 アルカリ処理によるフミン酸生成量 炭種粒径酸化酸华 $\mathrm{NaOH}$ 閔濃度酸生成成率 mesh ${ }^{\circ} \mathrm{C} \min \%$ 量 $\mathrm{mg} \%$

三 池 $60 \sim 80 \quad 200 \quad 60 \quad 2 \quad 000$

" 220 " 0 . 0

" $240 \quad$ " $\quad 2.750 .55$

" 250 " 2.50 .5

$\begin{array}{lllll}\text { " } 260 \quad 6.7 & 1.34\end{array}$

$\begin{array}{llllll} & 300 \quad & 7.3 & 1.46\end{array}$

" $\quad 90 \quad \begin{array}{lll}10.1 & 2.02\end{array}$

" $\quad 10$. $1.45 \quad 0.29$

" " 30 " -

" $\quad$ " $\quad 60 \quad 10 \quad 23 \quad 4.6$

大夕張 $60 \sim 100 \quad 200 \quad 60 \quad 2 \quad 000$

" 220 " $\quad 0 \quad 0$

$\begin{array}{lllll} & 240 \quad 0.85 & 0.17\end{array}$

$40 \sim 60 \quad 260$ " $\quad \begin{array}{lll}1.8 & 0.36\end{array}$

$60 \sim 100$ " " $7.3 \quad 1.46$

$40 \sim 60 \quad 340 \quad$ " $6 \begin{array}{lll}2.5 & 0.5\end{array}$

$\begin{array}{llllll}60 \sim 100 \quad 300 \quad & 10 & 21 & 4.2\end{array}$

田川

$\begin{array}{lllll}150 & 60 & 2 & 0 & 0\end{array}$

" $\Rightarrow \quad 0 \quad 0$

$200 \quad 60 \quad 1 \quad 1 \quad 0.2$

" $120 \quad 2.5 \quad 0.5$

" $180 \quad 11 \quad 2.2$

$250 \quad 60 \quad$ " $11.5 \quad 2.3$

" $120 \geqslant 17.03 .4$

$300 \quad 60 \quad 4.0 \cdot 0.8$

(d) アルカリ䞘理

第 2 表，第 9,10 汶に示したように，フミン酸の収量 は三池，大夕㖘炭では $300^{\circ} \mathrm{C}$ 酸化に抢いて最も多く， $300^{\circ} \mathrm{C}$ 酸化では酸化時間の多い程収量が多く, かつア ルカリ濃度が高い程，多量のフミン酸を得る。

田川宸では $250^{\circ} \mathrm{C}$ 酸化の厅がフミン酸量が多い。

第9図フミン酸生成量

酸化時間 60 分)

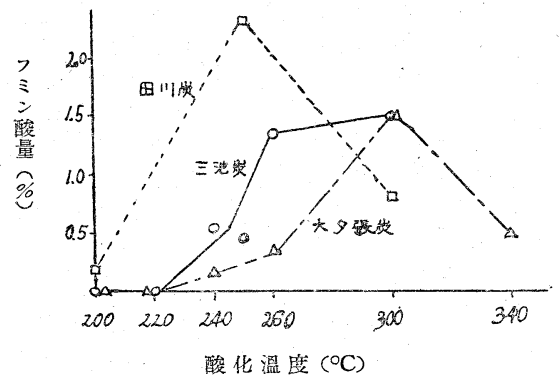

第10図 フミン酸全成量

三池茏 $(60 \sim 80 \mathrm{mesh})$

$3000^{\circ} \mathrm{C}$ 酸化

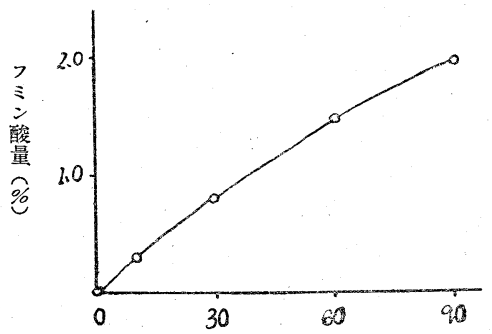

酸化時間 (min)

V 若

察

(a) 実験結果加らの推論

(1) 粘結性 実験結果にみられるように, 60mesh 以下の場合には $250^{\circ} \mathrm{C}$ 以下の温度では，反応の終点は

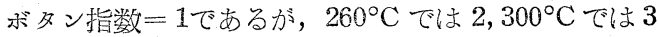
で市る。(三浙崖)

\section{第11図 溫度と最終ボタン指数} 三池炭 (60 80mesh)

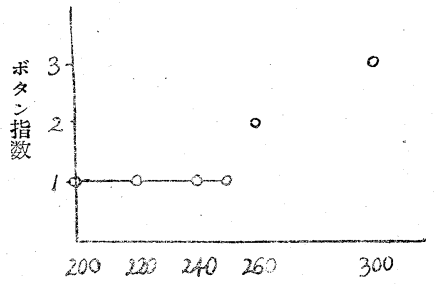

溫 茛 $\left({ }^{\circ} \mathrm{C}\right)$

この事柄は三池，大夕張炭で類似の傾问点示してい る。或一定の指数になつた後は，相当の時間酸化して も指数に変化はないから，反底が各段陛で一応終結し， ているとみられる。今このような現象就説明するには どのうな立場があるか考えてみると，「高温の方が 進んだ段階の反応が起きるために，粘結性の值が低温 の場合よりも大きい」と考えるか，あるいは「なんら かの專情で高温では石炭粒子の内部が末反応に留まる ために，みかけ上粘結性が大きくみえる」と考えるか のいづれかであろう。この闍題については後述する。

鹿町炭，米炭には酸化温度による差はないから，上 記の現象は三沲，大夕張炎の特性であろう。

笑験結果を他の文献と比較すると，粘結性を制御す る目的の條件として，50mesh 以下の粉宸党 $315^{\circ} \mathrm{C} て ゙$ $6.5 \mathrm{~min}^{14)}$, $8 \mathrm{mesh}$ 以下で $300^{\circ} \mathrm{C}$ で酸化する ${ }^{15)}$ と記 されている。この範囲は区応速度の点では三池, 大夕 張炭も含まれるが，上記の場合には鹿町，米炭のよう 
な炭種について考えていると思われる。三池炭につい ての報告 ${ }^{16)}$ ( 饭述速度が異ることおよび酸化曲線が 低下の傾向にあることなどで笔者の結果とは相違する が，温度特性は似ている。

（2）揮発分 高温程, 長時間程減少の傾向が著し いことは，反応機構が どのようであつても高温生成物 は低温生成物に比して揮発分の少いものであることが 確認される。

（3）重量変化 $200 \sim 300^{\circ} \mathrm{C}$ で $2 \mathrm{hr}$ 以内ではほと んど重量が変化していないことは，酸素附加量と孷 素, 水素の分解損失が大体等しいか, いずれもが少量 であることを示すものであるが，Reilly 2) の $180^{\circ} \mathrm{C}$ の実験によれば全消費酸素量が無水炭の $1.2 〜 47 \%$ の 時に重量增加は 0.3〜 4.4\% であるし，Lefebure ${ }^{9)} の$ $200 \sim 300^{\circ} \mathrm{C}$ の実験でも各温度で約 $17 \%$ の酸素が反応 した時の重量増加は $300^{\circ} \mathrm{C}$ で $0.6 \%, 200,250^{\circ} \mathrm{C}$ で約 $2 \%$ ある。酸化時間成同じ時にはゼトリットで 250 ${ }^{\circ} \mathrm{C}$ の時が増加が最も大きく $0.05 \mathrm{~mm}$ の粒径で $70 \mathrm{~min}$ 酸化の場合に $2 \%$ 増加㔔みられる。

（4）アルカリ処理 三池, 大夕張炭の粘結性变化 曲線に見受けられる温度による酸化生成物の質的相違 はここの場合にも著しくみられ，一定時間の酸化では 第 9 図にみられるように $240^{\circ} \mathrm{C}$ からフミン酸の量は急 速に増加しはじめ $300^{\circ} \mathrm{C}$ で最大になる。Kreulen ${ }^{8)}$

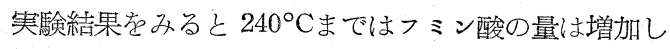
て行くが，大体 $240 \sim 300^{\circ} \mathrm{C}$ の温度で最大生成量にな ることが認められるが，これは田川，大夕張，三池炭 についてもいえるようである。

また第10図のように $300^{\circ} \mathrm{C}$ 酸化の場合に，時間が 10 min と $90 \mathrm{~min}$ では大きな差があるが，粘結性は $5 \mathrm{~min}$ 以後一定である事害に照らすと,アルカリ可溶形への 区応形式は粘結性低下の形式とは異つたものであるこ とが推察される。

（b） 区応速度について（三池，大夕張㟶）

各種類の分析結果を比較してみると, 区応形式が多 種類にわたつていることが考えられるが，石炭のよう な複雑な構造を持つ物質では反応に関与する構造も区 応機構も多種類になつていることは当然なのであろ う。

ここでは最も速く反応が起る粘結性反応について考 えてみる。反応終結時間と温度の関係を図に画くと第 12図のようになるが，この図から酸素の拡散速度の下 限を知ることができるので，反応速度の掘い反応（た とえばフミン酸を生成する反応）について粒径が異る 場合の反応必要時間の概略を推定することができる。

\section{第12図 粘結性反応粘結時間}

三池炭 (60 80mesh)

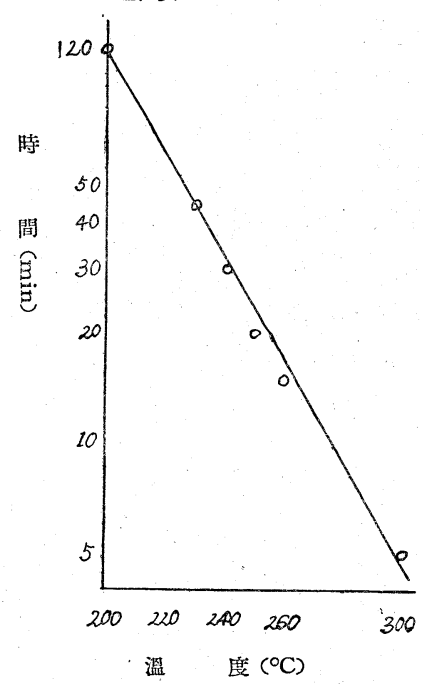

本実験は完全流動状態で行われたし，温度も比較的 低いから，区応粒子表面への酸素拡散に関するがス境 膜を考える必要はなく，同一反応條件では最も反応速 度の速い反応様式である。

（1） 反応速度式の導出

三池，大夕張炭の $60 \mathrm{mesh}$ 以下については $250^{\circ} \mathrm{C}$ 下の反応は, 温度特性からみて同種類の反応であるこ とが認められるし， $250^{\circ} \mathrm{C}$ 以下では反応終結時間が比 較的長く速度式の導出に便利であるのでこれについて 考察する。

今反応の進行途上において第13図のような反応界面 を仮想する。半径的の球面の内側を末反応部分, 外唄 を既反応部分とする。

区応は半径 通つて内部に移動する酸 素によつて起り, 移動酸 美量は界面の単位面積当 り単位時間につき一定と する。（化学区応速度が 反応の律速段階であると
第13図

\section{仮想反应界面}

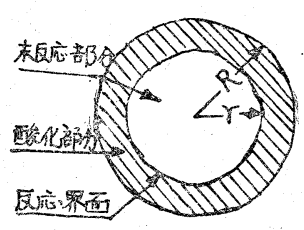

いう仮定である) 石炭の酸素拡散に対する抵抗が非常 に大きいとすれば，酸素の移動速度はその消費速度に 一致する。従つて

$$
\begin{aligned}
& \frac{d m_{0_{2}}}{d \theta} \propto-\frac{d r}{d \theta}=k, \text { より }(R-r)=k \theta, \\
& \text { あるいは }\left(1-\frac{r}{R}\right)=\frac{\theta}{\theta_{0}} \text { か導かれる。19\% } \\
&\left(\theta_{0} \text { : 反応終結時間 }\right)
\end{aligned}
$$


前式は正四面体，正六面体などの正立方体で反応界 面が原外形に相似的に移動する場合には式の成立條件 によつて適用可能であることが認められる。

（2）速度式の適用（粒径の異る場合）

粒径が異つても原炭抢よび反応終結炭の性質が等し い秳類のものについては，同一の性質を示すようにな るまでの酸化時間を比較することにより反応速度式を 検定できる。

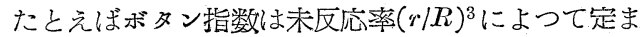
るが，外径が $R_{1}, R_{2}$ の粒径の粉炭がそれぞれ $\theta_{1}, \theta_{\dot{2}}$ 時 間後に同一ボタン指数を示した時には $(R-r)=k \theta$ の 式が正しいとすると， $\theta_{1} / \theta_{2}=R_{1} / R_{2}$ となるはずである ことが容易に導かれる。三池炭の $240^{\circ} \mathrm{C}$ 酸化の場合に 60〜80mesh と 100〜120mesh を比輘すると第 3 表の ようになり $R_{1} / R_{2}$ と $\theta_{1} / \theta_{2}$ はほぼ等しい。

\section{第3 表 粒径による反応速度の差異より}

\section{反応速度式の検定}

$$
R_{1} / R_{\Omega}=1.57
$$

$\begin{array}{rrrrrr}\text { ボ タ ン 指. 数 } & 3 & 2 & 1.5 & 1 \\ 60 \sim 80 \text { mesh } & \theta_{1}(\min ) & 10 & 1.7 & 20 & 30 \\ 100 \sim 120 \text { mesh } & \theta_{2}(\min ) & 5 & 10 & 1.3 & 20 \\ \theta_{1} / \theta_{2} & 2 & 1.7 & 1.5 & 1.5\end{array}$

ボタン指数が 3 の場合にはかなりの差異があるよう であるが， $\theta_{1} ， \theta_{2}$ は $10 \mathrm{~min}$ および 5 min であり試料

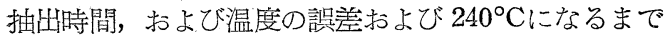
の時間の差が $\theta$ の小さい場合には影響することは止む を得ない。また反応終結物の性質は異なるが 50〜60 meshのものは 60〜80mesh，100〜120mesh と比較す ると，Rの比抢よび $\theta_{0}$ の比が $(1.3,1.33),(1.9,2)$ で

\section{第14図 酸化炭配合曲線}

三池原炭 (60 80mesh)

三池酸化炭 ( 》)

$240^{\circ} \mathrm{C}-30$ 分酸化しれもの

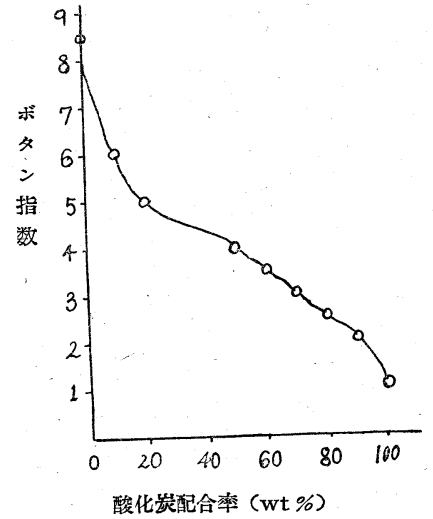

第15図 $\theta / \theta_{0}$ と $(r / R)^{3}$ の関係図

$\left(\frac{r}{R}\right)^{3}=\left(1-\frac{\theta}{\theta_{0}}\right)^{3}$

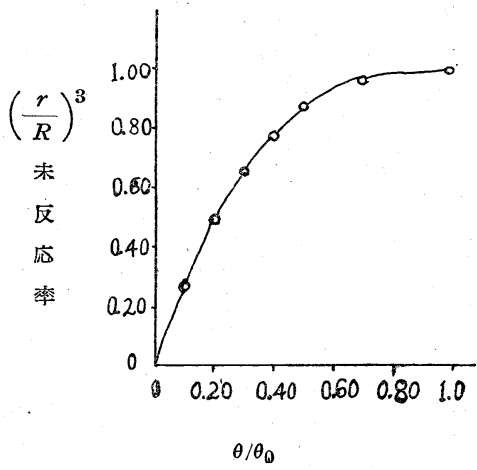

ありょく一致している。

（3） 反応速度式の適用（同一粒径の場合）

酸化終了炭は原炭に比してほとんど重量変化がない から，酸化炭之原炭との重量比配合曲線（第14図）を 使用する。

第 14 図でボタン指数が $\mathrm{Nm}$ の時の配合率を $x$ とす る。 $(1-r / R)=\theta / \theta_{0}$ が成立するとして画いた $(r / R)^{3}$ と $\theta / \theta_{0}$ の曲線（第15図）に㧤いて $x=(r / R)^{3}$ に相当 する $\theta / \theta_{0}$ を求め, 粘結性変化曲線の図で $\theta$ 時間のボ タン指数 $N_{0}$ を求めて， $N_{0}$ と $N_{m}$ が等しければ速度 式が認められることになる。その結果を第 4 表に示し たが $N_{0}$ と $N_{m}$ は大体一致している。

第 4 表 配合曲線による反応速度式の検定

i ）三池炭 $240^{\circ} \mathrm{C}$ 酸化の場合
1. $60 \sim 80$ mesh
2. 100 120mesh

$\begin{array}{lllllllll}\theta / \theta_{0} & 0.2 & 0.4 & 0.6 & 1.0 & \theta / \theta_{0} & 1 / 3 & 2 / 3 & 1\end{array}$

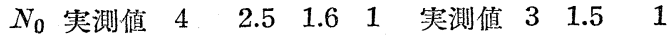

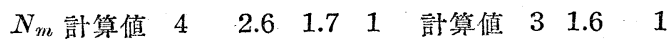

ii) 三池炭 $250^{\circ} \mathrm{C}$ 酸化の場合(60〜80mesh)

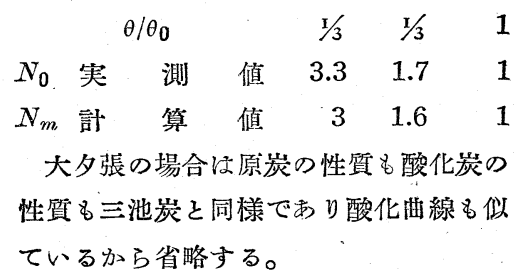

上述のように種々の仮定が含まれたが，みかけ上

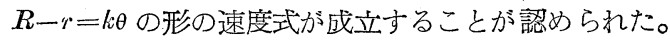
速度式の検討にはとの他の方法，たとえば揮発分，ア ルカリ可溶量などによる検定の方が方法としては厳密 であるが，粘結性となつて現われる最も速い反応形式 についての速度式の検定法としてはこの程度のもので 
あろう。

（4）従来の反応速度式との比較

(i ) 時間抢よび粒径の影響について

酸素消費速度については $150^{\circ} \mathrm{C}$ 以下で次の式が実験 に合うといわれている。

\section{$X=C_{\theta}{ }^{b} \quad X$; 酸素消費量 $\theta$; 時間}

$O$; 常数 $b$; 粒径により定まる数, 一200meshで で $0.37,0 \sim 1 / 4$ "で 0.8 ,

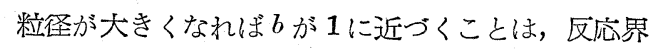
面について考慮すべきことを示している。粒径が小さ くなると界面は速く内部に移行するから $\frac{d X}{d \theta}$ は時間が 増すにつれて急速に減少するはずである。

$R-r=k \theta$, ょり $X$ を導くと

$X=k\left\{1-\left(\frac{r}{R}\right)^{3}\right\}=O_{1} \theta-O_{2} \theta+O_{3} \theta^{3} \fallingdotseq O_{1} \theta-O_{2} \theta$

この式は $X=C_{\theta} b(0<b<1)$ に近似的に等しいが

（粒径大 $b \rightarrow 1$, 粒径小 $b \rightarrow 0) \quad X=O_{\theta} b$ の方が適用範围 も狭く式の意味も不明確であるように思われる。 $X=$ $O_{1} \theta-O_{2} \theta^{2}$, あるいは(C)-(1)に導いた式より $X$ を 表現する方が道切であろう。

また試料の表面積を $S$ とすると酸素消費速度 $v$ が

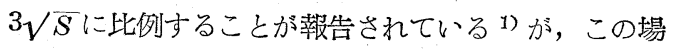
合も反応界面の考慮が不足している。反応が内部まで 進行する時には初期では $v=k S$ であるし, 終期には $v=k S^{0}$ となり, 近似的に $v=S^{a}(0>a>1)$ が成立する ことになる。

なお反応方法によつては, 粒子表面への酸素拡散速 度が粒径によつて異ること（ガス境膜により）も考え ねばならない。

反応速度式は区応が 1 つの形式で起るのではないか ら，近似的であり時閒的にも限界を有することは止む を得ない。

（ii）温度の影響（活性化エネルギ）

第 2 図で反応終結時間は $200,220,240,250^{\circ} \mathrm{C}$ で それぞれ 120，60，30，20min である。この差異が化 学反応速度の美異によつて起つたものとするとArrehenius の式から活性化ェネルギを求めることができ る。 $1 / T^{\prime}$ と1/ $\theta\left(T^{\prime}\right.$ : 絶対温度, $\theta$; 反応終結時間) の 関係はほとんど直線になり，この結果 $200 \sim 250^{\circ} \mathrm{C}$ で は $E=18 \mathrm{kcal} / \mathrm{mol}$ であることを認めだ。

参考として他の実験者の測定值をあげてみる。

Kreulen ${ }^{1)} ; 27.6 \mathrm{kcal} / \mathrm{mol}\left(220^{\circ} \mathrm{C} \sim 260^{\circ} \mathrm{C}\right)$

Gladstone; $16 \mathrm{kcal} / \mathrm{mol}\left(84^{\circ} \mathrm{C}\right.$ 以下) $25.3 \mathrm{kcal} / \mathrm{mol}\left(84^{\circ} \mathrm{C}\right.$ 以上)

（C） 反応の進行機構について. (三池，大夕張炭)
第2,3図に示したように，反応温度が $250^{\circ} \mathrm{C}$ 以下と 以上ではみかけ上の反応終結物のボタン指数が明らか に異つているという興味ある事寒を認めた。

これは考察の第 1 項に述べたのであるが，その性質 の相違が「内部まで反応が起つているのに生成物が異 質である」ことによるのかあるいは「表面のみが反応 して内部が未反応の状態にある」ことによるのか考察 してみる。

笔者の実験結果によれば前者を支持する根拠が多い が，岩崎氏 ${ }^{16)}$ は表面近くのみが反応して，生成した 酸化被膜が酸素の拡散を阻止しているために，みかけ 上高い指数に留まるのであり, 反応速度の低下に起因 すると云う後者の立場を述へておられるので, 以下に 例証を上げて論ずることにする。

(1) 酸化生成物の拡散抵抗について

反応速度の項で考えた反応の進行模型において，酸 化終了部分の拡散抵抗が反応の律速段階であり酸素拡 散が Fick の式 $d_{m 0_{2}}=-D \frac{d e}{d r} \cdot d \theta$ に従うとすると， (b) - ( 1 ) と同様な仮定から

$$
\theta / \theta_{0}=1-3\left(\frac{r}{R}\right)^{2}+2\left(\frac{r}{R}\right)^{3}
$$

が導かれる。これを $(r / R)^{3}$ と $\theta / \theta_{0}$ について図示する と第16図のようになり， $\theta$ の変化に対して $(\theta / R)^{3} す$ なわち末反応率は相当変化するから，たと元酸化生成 物の酸素拡散抵抗が非常に大きくても $300^{\circ} \mathrm{C}$ 酸化で 5 min, 60min, $120 \mathrm{~min}$ でボタン指数が等しい事寒か らすれば，最終指数が $250^{\circ} \mathrm{C}$ 以下のものよりも大きい 点に疑問があつても, $300^{\circ} \mathrm{C} て ゙ は$ 約 $5 \mathrm{~min}$ で粘結性に 関する反応のほとんどは内部においても終つており， 最終指数は三池では 3 , 大夕㖘では 2.5 であるとする 方が数量的な矛盾を有しない。

実例として被膜が岩崎氏の観察されたように，10 と仮定してみる。これは 60〜80 mesh の粒径ではr/R が 0.9 に相当寸る場合であり, 未反応率は 0.73 であ る。この時の $\theta / \theta_{0}$ は 0.028 であるから, 第 16 図から

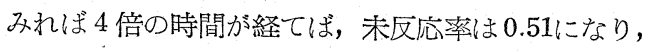
当然ボタン指数にも著しい変化がなければならない し，18倍の時間後にはほとんど反応が終結することに なり生成物が非粘結性物とすれば非粘結になるはずで ある。

このようなことは，たとえ被膜をどの位の厚さに仮 定したところで，その厚さがボタン数を 3 の程度に低 下せしめる程の厚さであれば，常に同様な結論を得る ものである。

（2）粘結性の恢復について 
第16図 被膜抵抗と未历応率

$\frac{\theta}{\theta_{\theta}}=1-2\left(\frac{r}{R}\right)^{2}+3\left(\frac{r}{R}\right)^{3}$ における $\frac{\theta}{\theta_{\theta}} \gtrsim\left(\frac{r}{R}\right) r$ の関係図

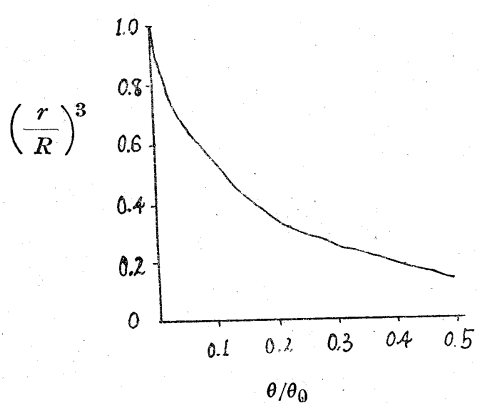

反応が内部にまで起つており，300 $\mathrm{C}$ の反応が 250 ${ }^{\circ} \mathrm{C}$ 以下の反応よりも高次のものであることを証明す るのには, $250^{\circ} \mathrm{C}$ 以下の温度でボタン指数を1にした

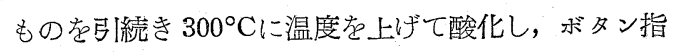
数の変化の終点が，直接に $300^{\circ} \mathrm{C}$ で酸化した場合の指

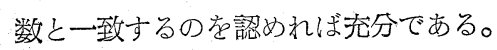

第17図に, $240^{\circ} \mathrm{C}$ で $30 \mathrm{~min}$ 酸化してボタン指数を 1 にしたものを，さらに $300^{\circ} \mathrm{C} て ゙$ 酸化した場合の変化曲 線と，原崖を直接に $300^{\circ} \mathrm{C}$ で酸化した場合の変化曲線

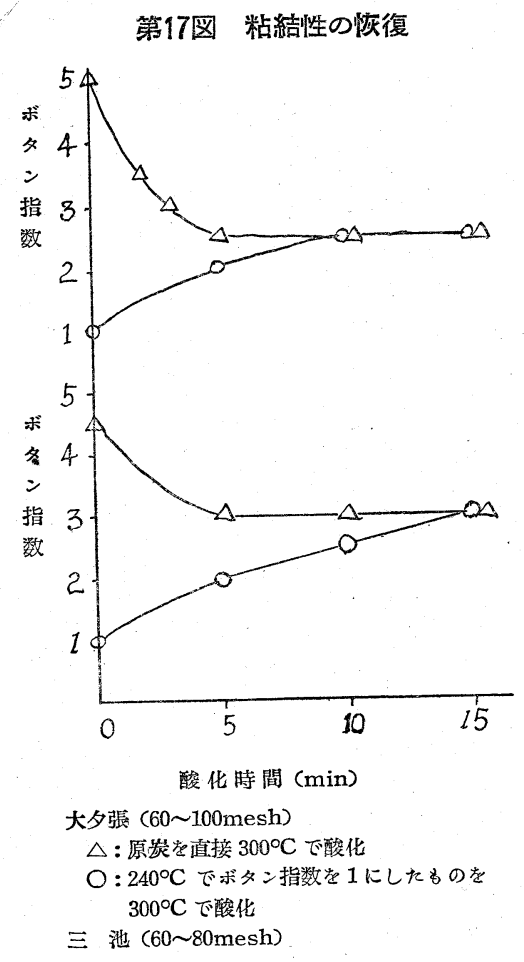

とを比較して示した。図のように，時間的なずれはあ るが 10〜15 $\mathrm{min}$ 以後のボタン指数は完全に一致して いる。この高温で粘結性が恢復するという事实は, 粘 結性の低下が酸素の附加反応により起るものであり, 高温ではこの構造部分がさらに反応して, 熱流動性が 増加するのであろうということを推測させる。

(3) アルカリ処理の結果について

$250^{\circ} \mathrm{C}$ 以下と $260^{\circ} \mathrm{C}$ 以上の反庍の差は，アルカリ処 理の結果得られるフミン酸の量において顕著である (第 9 図)また第10図のようにフミン酸の量は, 酸化時 間の長い。程多く，酸素が拡散して酸化が進行してい るのがみられる。

高温のアルカリ処理では，未処理炭はわずかしか溶 けず， $300^{\circ} \mathrm{C}, 10 \mathrm{~min}$ 酸化宸と $300^{\circ} \mathrm{C}, 120 \mathrm{imn}$ 酸化 炭の間には大きな差があり，また $300^{\circ} \mathrm{C}, 90 \mathrm{~min}$ 酸化 炭は， $240^{\circ} \mathrm{C}, 90 \mathrm{~min}$ 酸化崖よりも遥かによく溶解す ることが観察された。

これらの事実は，（被膜が拡散を阻止する） $300^{\circ} \mathrm{C}$ 酸化がごく薄い被膜にのみ反応が限られているという 考え方からは説明できない事柄である。

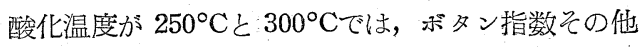
の性質が異るのは，高温程段階の進んだ区応が起るこ とによると考える方が，これらの結果をよく説明でき るしこの考え方を実験結果が支持している。（加熱 の影響については，絓素気流中の実験を行つて確かめ

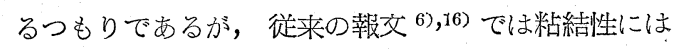
影響がないようである。)

\section{VI 結}

論

以上の実験結果から次のような結論を得た。

（1）空気酸化の化学区応は高温になる程進んだ段 階の反応が起るために，酸化温度により石㞸の種類に よつては酸化生成物の性質がかなり異ることがある。

（2）粘結性を低下させる目的では, 大夕張, 三池

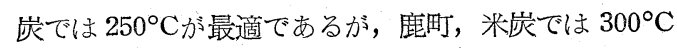
位の高温の方が反応速度が速く有利である。

（3）重量の変化は，60～80meshの石炭では，200 〜300 Cの温度で $2 \mathrm{hr}$ 酸化した範囲では，ほとんぎ認 められない。

(4) 揮発分は高温程著しく減少する。粒径の小さ い程速度は速い。( 3 )の結果を参照すると高温程不揮 発分の増加は著しい。

（5）アルカリ可溶のフミン酸を得るには，三池， 大夕張炭では $300^{\circ} \mathrm{C}$ 近くの温度が時間的にいつて最適 であり，田川炭では $250^{\circ} \mathrm{C}$ 近くが適当であると認めら れる。 
（6）三池，大夕張炭では $240^{\circ} \mathrm{C} ， 250^{\circ} \mathrm{C}$ の酸化で は, 反応界面の移動について $R-r=k \theta$, あるいは 1 $r / R=\theta / \theta_{0}$, を適用できる。

この式の意味は，界面の移動速度が一定であるとい うことであり，その速度は $240^{\circ} \mathrm{C} て ゙ ~ 0.2 \mathrm{~mm} / \mathrm{hr} ， 250$ ${ }^{\circ} \mathrm{C}$ では $0.3 \mathrm{~mm} / \mathrm{hr}$ であると認められる。上式は粒径 分布が或る場合の未反応率の計算あるいは酸素の拡散 速度の下限を知る上に適用される。

（7）粘結性に大きな影響を与える区応と，フミン 酸生成に大きな影響を与元る反応では，前者の方が時 間的に速く起り得るものであり，かつ両者の反応に関 与する構造および反応生成物は異ると考えられる。

（8）三池，大夕張炭にみる $300^{\circ} \mathrm{C}$ 酸化のボタン指 数の最終值肪， $250^{\circ} \mathrm{C}$ 以下の值よりも高いのは，酸化 反応の段階が進んでいるためと考えられる。

（9）揮発分が高く，熱流動性の大きい石炭は適当 に酸化すれば揮発分の低い，蓺流動性の小さい石炭に なるからこれをそのままあるいは未処理炭と配合し てコークスを作れば, コークスは固くなりその収率は かなり堌加することが予想される。

[附記]

本研究は東京大学工学部灾用化学科燃料工学研究室 に抢いて安東新午教授および石川馨助教授の御指導の 下に行なわれたものである。終始御懇篤なる御指導を 戴いた両先生に深謝の意を表する。

$$
\text { 交献 }
$$

1) H. H. Lowry, "Chemistry of Coal Utilization"
627 76, (1950).

2) 同上 859 62 (1950).

3) 同上 346 58 (1950).

4) Schmidt, Ind. Eng. Ohem,. 28, 1346 53(1936).

5) 香坂要三郎, 石炭の化学, 119 22, (1951).

6) D. J. W. Kreulen, Brenn. Ohem,. 8, 241 44 (1927).

7) G. T. Morgan, J. Soc. Ohem. Ind. (Trans.). 57, 389 92 (1938).

8) D. J. W. Kreulen, Brenn. Ohem., 15, 11 12 (1934).

9) H. Lefebure, Brenn. Ohem., 18, 141 42 (1937).

10) G. Fuchs, Ind. Eng.Ohem., 35, 343 46 (1943).

11) D. H. Bangham, "Progress in Coal Science", 282 95 (1950).

12) O. Grosskinsky, Glückanf, 88, 376 (1952).

13) G. Huck, Brenn. Chem., 54, 97 102 (1953).

14) U. S. P, 2,560, 478 (1951).

15) Ohem. Eng., 59, 204 46 (1952).

16）岩崎高雄，石炭のコークス化化関する研究，296 〜364 (1953).

17）樋口耕三，㗄源技術試験所研究記錄（英交)，21 (1951 1952)

18）井上勝也，燃研報告， 66号，47〜53 (1952).

19）矢木 ·国井, 化学工学, 16, 283 87 (1952).

\title{
Air-0xidation of Coal ( I ) \\ Reaction Velocity, Oxidation Products and Reaction Mechanism in Fludized-Zone Reaction of Coal
}

\author{
by Yoshio Kamiya
}

(Tokyo University)

\begin{abstract}
SYNOPSIS :-Some probrems of air oxidation (mainly $200 \sim 300^{\circ} \mathrm{C}$ ) were studied by means of fludized-zone reaction apparatus. The changes in caking property, volatile matter, weight and fumic acid by oxidation were measured. Accoding to the results of above experiments, the natures of oxidation products were changed by the coal grades and oxidation temperatures. In addition, the author mentioned some considerations. on the reaction mechanisms, showed the formula of $R-r=k \theta$.
\end{abstract}

